\title{
TEKNOLOGI IRIGASI OTOMATIS BERTENAGA SURYA DI KELOMPOK TANI CAHAYA TANI KECAMATAN TARAKAN UTARA KOTA TARAKAN
}

\author{
Sudirman Sirait ${ }^{1}$, Dwi Santoso ${ }^{2}$, Saat Egra ${ }^{3}$ \\ 1,2,3 Jurusan Agroteknologi Fakultas Pertanian Universitas Borneo Tarakan \\ Jalan Amal Lama Nomor 1 Kelurahan Pantai Amal, Kota Tarakan, 77123. \\ E-Mail: sudirsirait@gmail.com
}

Received: 25 July 2019

Accepted: 12 September 2019

\begin{abstract}
One effort to increase irrigation efficiency is the use of solar power-based automatic control systems. This technological innovation was designed by utilizing digital technology, microcontroller and sensor network. This automatic control system operates based on the value of soil moisture as the lower set point value and the upper set point value to set the pump on/off. The aims of this research are to develop a solar-powered automatic control system with reference to the control of soil moisture for set on/off the pump and can keep the soil moisture from the water capacity. The stages of the research are hardware design of solar-powered control systems, design of automatic control system software, design of sprinkler irrigation networks, testing and data analysis. The results showed that the total power to operate an automatic sprinkler irrigation system of $67.0 \mathrm{Watt}$ and can reduce battery consumption of 234.7 Watt. The use of a $30 \mathrm{Wp}$ solar panel unit is able to meet the power needed for the automatic control system during the experiment.
\end{abstract}

Keywords: automatic control system, microcontroller, solar power, sprinkler irrigation

\begin{abstract}
ABSTRAK
Salah satu usaha untuk meningkatkan efisiensi irigasi adalah penggunaan sistem kontrol otomatis berbasis tenaga surya. Inovasi teknologi ini dirancang dengan memanfaatkan teknologi digital, mikrokontroller dan jaringan sensor. Sistem kontrol otomatis ini beroperasi berdasarkan nilai kelengasan tanah sebagai nilai set point bawah dan set point atas untuk mengatur on/off pompa. Penelitian ini bertujuan untuk mengembangkan sistem kontrol otomatis bertenaga surya dengan acuan kendali kelengasan tanah untuk pengaturan on/off pompa dan menjaga kondisi tanah dari kapasitas lapang. Tahapan penelitian yaitu perancangan hardware sistem kontrol otomatis bertenaga surya, perancangan software sistem kendali, perancangan jaringan irigasi sprinkler, pengujian dan analisis data. Hasil percobaan menunjukkan total daya untuk mengoperasikan sistem irigasi sprinkler otomatis 67,0 Watt dan menghemat penggunaan daya baterai sebesar 234,7 Watt. Penggunaan 1 unit panel surya $30 \mathrm{Wp}$ mampu mencukupi daya yang dibutuhkan untuk mengoperasikan sistem kontrol otomatis selama percobaan.
\end{abstract}

Kata kunci: irigasi sprinkler, mikrokontroller, sistem kontrol otomatis, tenaga surya

\section{PENDAHULUAN}

Kecamatan Tarakan Utara secara geografis berada antara $117^{\circ} 31^{\prime} 45^{\prime \prime}-117^{\circ} 38^{\prime} 12^{\prime \prime}$ Bujur Timur dan $3^{\circ} 14^{\prime} 30^{\prime \prime}-3^{\circ} 26^{\prime} 37^{\prime \prime}$ Lintang Utara dan merupakan salah satu pemasok hasil pertanian untuk wilayah Kota Tarakan. Potensi hasil sektor pertanian wilayah Kecamatan Utara adalah tanaman pangan, sayur-sayuran dan buahbuahan. Hal ini sangat memungkinkan untuk kegiatan budidaya dan pengembangan usaha tani yang dapat mendukung ketersediaan hasil pertanian wilayah Kota Tarakan. Namun kegiatan usahatani di wilayah Kecamatan Tarakan Utara masih menerapkan sistem tadah hujan yang berdampak pada ketidakpastian pemenuhan kebutuhan air oleh tanaman. Kondisi ini menyebabkan ketidakseimbangan antara ketersediaan dan kebutuhan air tanaman, penurunan produksi atau bahkan gagal panen. Pengelolaan air berperan sangat penting dan merupakan salah satu kunci keberhasilan peningkatan produksi hasil tanaman pertanian. Pertumbuhan dan perkembangan tanaman bisa terhambat atau terganggu karena kebutuhan air tidak tercukupi. Tusi dan Lanya (2016) menjelaskan bahwa salah satu kendala yang dihadapi oleh kelompok tani kecil dalam meningkatkan produktivitas tanaman dan pendapatannya adalah lemahnya akses untuk mendapatkan teknologi irigasi.

Permasalahan air bidang pertanian adalah persoalan ketidaksesuaian distribusi air irigasi untuk kebutuhan tanaman. Pengaturan 
pemberian air di lahan pertanian sangat sulit jika masih dilakukan dengan cara manual yang selama ini banyak dipakai oleh petani, maka diperlukan suatu sistem pemberian air irigasi yang lebih efektif dan efisien. Salah satu cara penyediaan kebutuhan air tanaman untuk meningkatkan produksi hasil pertanian adalah sistem irigasi sprinkler yang dilengkapi dengan sistem otomatis berbasis tenaga surya. Siebert dan Doll (2010) memperkirakan bahwa rata-rata hasil produksi tanaman biji-bijian dengan sistem irigasi adalah 4,4 ton/ha, sedangkan dengan sistem tadah hujan sebesar 2,7 ton/ha. Sebesar $42 \%$ dari hasil produksi tanaman biji-bijian pada umumnya berasal dari lahan irigasi dan tanpa sistem irigasi hasil produksi akan menurun sebesar $20 \%$.

Penerapan teknologi inovasi irigasi sprinkler otomatis berbasis tenaga surya pada lahan usahatani merupakan salah satu pilihan yang menjanjikan karena teknologinya sederhana, aplikatif, biayanya relatif murah dan dapat terjangkau oleh petani. Mikrokontroller Arduino Uno ATMega328P dapat digunakan sebagai sistem kendali otomatis untuk pengaturan on-off pompa irigasi dan dapat mendukung produktivitas tanaman. Nurfaijah et al. (2015) menyatakan bahwa sistem kontrol tinggi muka air berdasarkan sistem kendali onoff menggunakan mikrokontroler Arduino Uno ATMega328P dengan perlakuan rejim air agak basah untuk budidaya tanaman padi memberikan jumlah anakan tertinggi (138 anakan), hasil tanaman tertinggi 194,7 g/rumpun (setara 21,6 ton/ha dengan asumsi jarak tanam $30 \times 30 \mathrm{~cm}$ ), dan produktivitas air tertinggi $3,16 \mathrm{~kg} / \mathrm{m} 3$.

Pemanfaatan tenaga surya telah banyak digunakan oleh masyarakat luas baik untuk kepentingan pertanian maupun non pertanian, sehingga sangat memungkinkan untuk digunakan sebagai sumber energi untuk penggerak outlet irigasi elektromekanis. Sel surya dapat mengonversi sekitar 30\% dari energi radiasi matahari menjadi listrik (Ingale dan Kasat, 2012; Uddin et al, 2012; Balaji dan Sudha, 2016; Chavan et al, 2017). Pemanfaatan tenaga surya sebagai sumber energi untuk irigasi sprinkler juga telah dilakukan oleh Sirait dan Sri (2018) yang menyatakan bahwa sistem kontrol dapat beroperasi sesuai dengan set point yang ditentukan yaitu pengaturan tingkat kelembaban tanah $13,58 \%$ sebagai nilai set point bawah dan $28,29 \%$ sebagai nilai set point atas untuk acuan pengaturan on-off pompa irigasi serta dapat menjaga kondisi tanah dari kapasitas lapang.
Berbagai uji coba dan penelitian irigasi otomatis dengan tenaga surya telah dilakukan dengan simulasi komputer untuk mengoperasikan pompa irigasi berdasarkan kelembaban tanah sebagai acuan kendali. Hasil model simulasi tersebut diimplementasikan pada skala laboratorium dan lahan kering untuk bidang pertanian ukuran medium (Dursun dan Ozden, 2012; Uddin et al, 2012; Nagahage \& Dilrukshi, 2012; Alam dan Naseem, 2014). Saptomo et al. (2013) mengatakan bahwa pengondisian lengas tanah volumetrik diantara $38,5 \%$ dan $28,7 \%$ sebagai acuan untuk mengoperasikan solenoid valve pada irigasi curah dapat mencegah kekurangan air dan sekaligus menghindari perkolas. Tujuan penelitian ini adalah mengembangkan sistem kontrol otomatis bertenaga surya dengan acuan kendali kelengasan tanah untuk pengaturan on/off pompa di lahan Kelompok Tani Cahaya Tani Kecamatan Tarakan Utara Kota Tarakan. Teknologi irigasi sprinkler otomatis bertenaga surya dapat digunakan untuk mempermudah pemberian air untuk tanaman berdasarkan tingkat kelembaban tanah di lahan pertanian, meningkatkan efisiensi penggunaan air irigasi dan efisiensi tenaga kerja.

\section{Lokasi Penelitian}

\section{BAHAN DAN METODE}

Penelitian dilakukan di lahan Kelompok Tani Cahaya Tani Kecamatan Tarakan Utara Kota Tarakan pada bulan Februari-Juni 2019. Penelitian dibagi ke dalam beberapa tahapan yaitu perancangan hardware sistem kontrol otomatis bertenaga surya, perancangan software sistem kendali, perancangan jaringan irigasi sprinkler, pengujian dan analisis data.

\section{Alat dan Bahan}

Alat dan bahan yang digunakan dalam penelitian ini adalah Mikrokontroller Arduino Uno ATMega328P, pompa, sensor kelembaban tanah YL-69, micro SD, RTC modul, baterai 12 Volt, relay 12 Volt dan 5 Volt, panel surya 30 WP, solar charge controller, kotak panel, terminal barrier, pipa PVC, dan sprinkler.

\section{Rancangan Hardware}

Perangkat hardware teknologi irigasi sprinkler otomatis bertenaga surya terdiri dari panel surya, panel sistem kendali, rangkaian sensor kelembaban tanah, dan catu daya.

Sistem kontrol otomatis dibangun dengan memanfaatkan teknologi digital, mikrokontroller dan jaringan sensor. Mikrokotroller digunakan sebagai sistem kendali otomatis untuk menggerakkan sistem aktuasi 
pompa irigasi berdasarkan kelembaban tanah di lahan percobaan yang dideteksi oleh sensor. Panel sistem kendali terdiri dari mikrokontroler, inverter, relay, rangkaian sensor, baterai dan solar charge controller. Mikrokotroller diaktifkan melalui koneksi USB atau dengan catu daya eksternal. Daya berasal dari baterai dan dihubungkan dengan menancapkan plug jack ukuran 2,1 mm ke konektor power. Konsumsi daya yang dibutuhkan untuk board Mikrokotroller adalah 7 sampai dengan 12 Volt. Gambar 1 menunjukkan rangkaian hardware sistem kontrol irigasi sprinkler otomatis bertenaga surya.

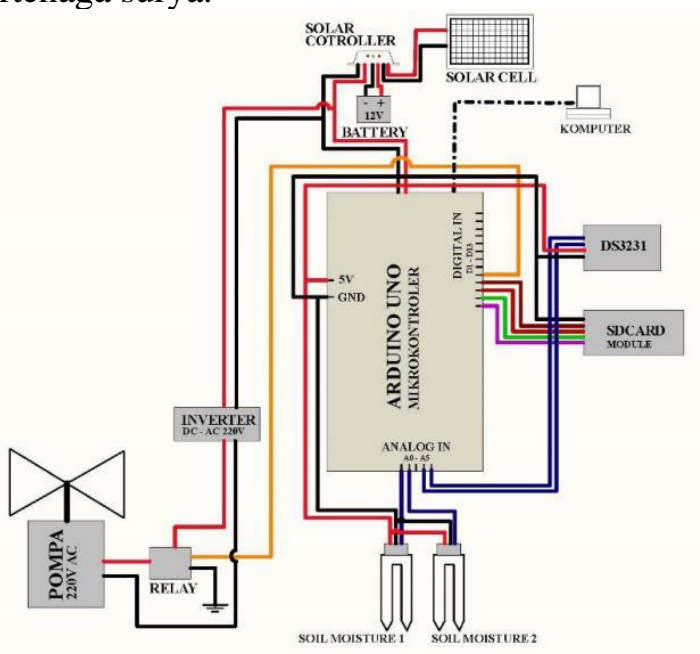

Gambar 1. Skema rangkaian hardware

\section{Rancangan Software}

Pada tahap perancangan software dilakukan pembuatan dan penyesuaian program untuk melakukan serangkaian pengujian sistem otomatis. Penulisan program kendali ditulis di halaman Arduino Uno. Bahasa pemograman didasarkan pada bahasa pemograman $\mathrm{C} / \mathrm{C}++$. Nilai setpoint ditentukan berdasarkan hasil analisis kadar air tanah lahan usahatani dan menjaga kondisi tanah dari kapasitas lapang. Kelembaban tanah dideteksi oleh sensor YL-69 dan mengirimkan ke mikrokontroler. Sensor kelembaban tanah berkomunikasi dengan komputer melalui USB serial port. Komputer berfungsi sebagai antar muka pengguna untuk memonitor dari hasil pembacaan sensor, waktu dan aktivitas sistem kendali irigasi, serta untuk mengubah setting pengendali yang diinginkan.

Ketika kondisi kelembaban tanah berada dibawah setpoint bawah maka mikrokontroler akan memberikan sinyal untuk mengaktifkan relay yang akan mengaktifkan motor pompa untuk on. Demikian juga sebaliknya ketika kelembaban tanah berada diatas setpoint atas, maka mikrokontroler akan memberikan sinyal untuk mengaktifkan relay dan menggerakkan motor pompa untuk off. Ketika kelembaban tanah berada antara nilai setpoint atas dan bawah maka status motor pompa adalah idem. Bagan alir rancangan sistem kendali irigasi otomatis bertenaga surya dapat dilihat pada Gambar 2 .

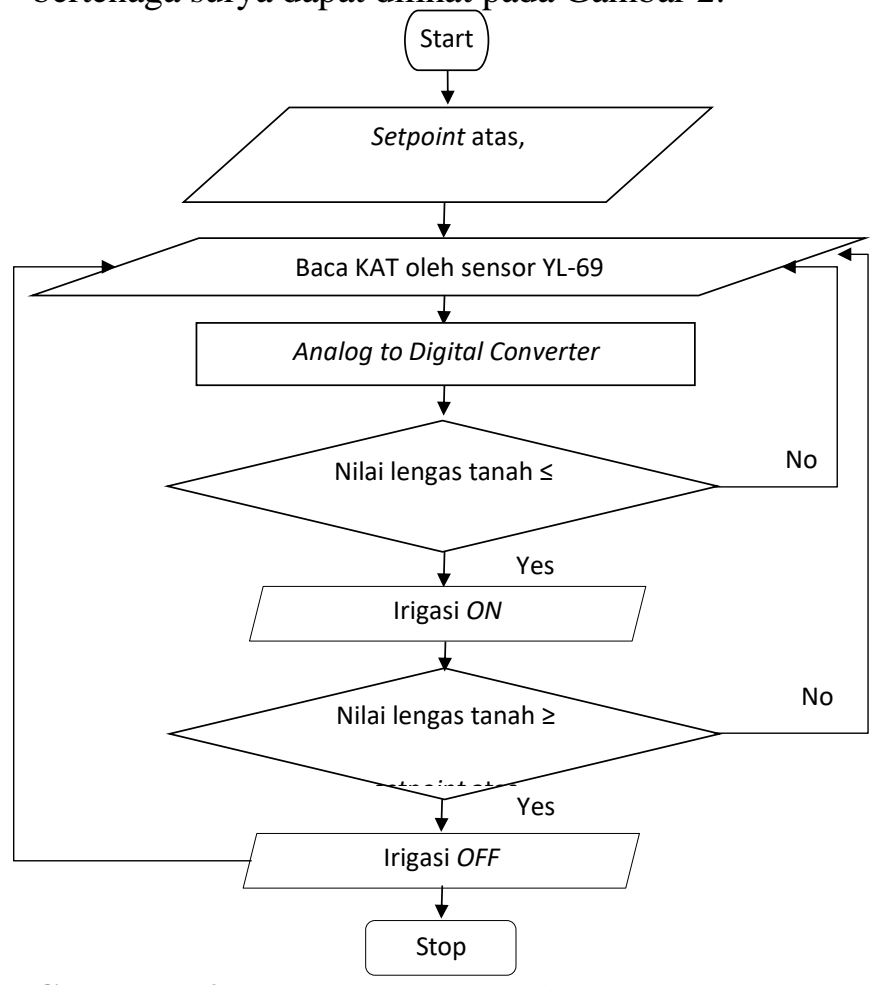

Gambar 2. Diagram Alr Sistem Kendali Otomatis

\section{Rancangan Jaringan Irigasi Sprinkler}

Rancangan jaringan irigasi pompa perpipaan dipasang pada lahan usahatani seluas 1 ha dengan menggunakan sistem perpipaan dan sistem pengaliran menggunakan tekanan pompa. Pipa utama yang berdiameter 1 inchi mengalirkan air ke pipa lateral yang berdiameter $1 / 2$ inchi dan merupakan outlet irigasi. Pemberian air untuk tanaman dilakukan dengan metode penyiraman curah menggunakan sprinkler berjarak $6 \mathrm{~m}$ antar sprinkler. Air irigasi bersumber dari air tanah yang terdapat di lahan usahatani dan jaringan juga dilengkapi dengan simpang by pass yang digunakan jika sistem mengalami trouble. Gambar 3 memperlihatkan instalasi jaringan irigasi pompa sistem perpipaan di lahan usahatani yang dilengkapi dengan sistem kontrol otomatis bertenaga surya. 


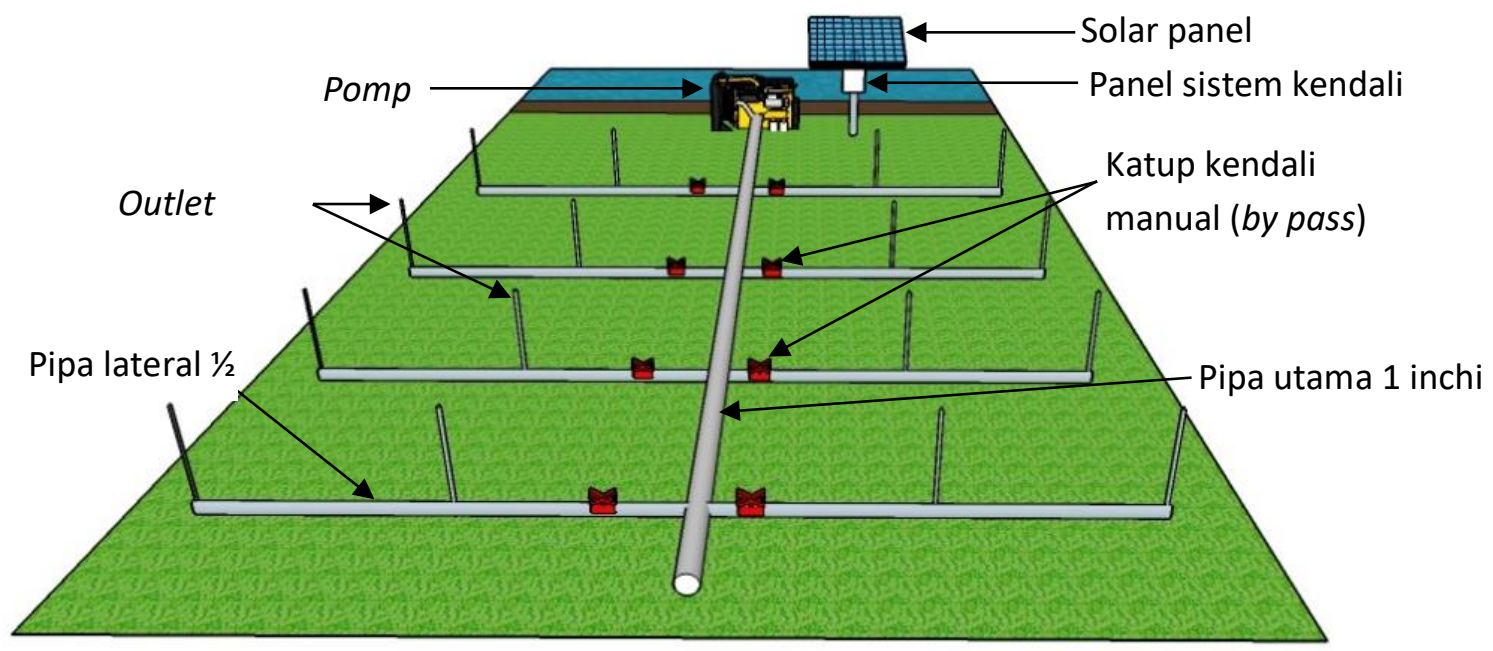

Gambar 3. instalasi jaringan irigasi sprinkler sistem perpiaan di lahan usahatani

\section{Analisis Data}

Analisis dilakukan agar data hasil pengujian dapat digunakan dan dijadikan rujukan untuk penyempurnaan sistem lebih lanjut. Data yang dianalisis meliputi perangkat software dan hardware, instalasi jaringan irigasi sprinkler, dan analisis konsumsi daya untuk pengoperasian sistem. Data yang dianalisis dapat menggambarkan kinerja sistem kontrol otomatis pada irigasi sprinkler dengan set point yang diinginkan.

\section{HASIL DAN PEMBAHASAN}

\section{Perangkat Software dan Hardware}

Perancangan software dilakukan pembuatan dan penyesuaian program untuk melakukan serangkaian pengujian sistem otomatis. Penulisan program kendali ditulis di halaman Arduino Uno. Bahasa pemograman didasarkan pada bahasa pemograman $\mathrm{C} / \mathrm{C}++$. Program kendali ditentukan dengan berdasarkan nilai kelengasan tanah lahan percobaan sebagai nilai set point untuk mengoperasikan pompa. Halaman Arduino Uno ATMega328P merupakan tempat penulisan pemograman untuk pengoperasian dengan waktu delay 5 detik. Pemograman dilakukan dengan menggabungkan kodingan masing-masing perangkat hardware pada sistem. Pada tahap perancangan hardware dilakukan dengan menggabungkan masingmasing perangkat dengan Arduino Uno ATMega328P melalui kabel jumper pada setiap pinnya. Arduino Uno ATMega328P mempunyai
14 digital input/output (6 diantaranya dapat digunakan untuk PWM output), 6 analog inputs, $16 \mathrm{MHz}$ clock speed, USB connection, power jack, ICSP header, dan reset button. Skema Arduino Uno ATMega328P disajikan pada Gambar 4. dengan ciri-ciri sebagai berikut :

1) Operating voltage 5 Volt.

2) Rekomendasi input voltage 7-12 Volt.

3) Batas input voltage 6-20 Volt

4) Memiliki 14 buah digital input/output

5) Memiliki 6 buah Analog Input.

6) $D C$ current setiap I/O Pin sebesar 40 $\mathrm{mA}$.

7) $\quad D C$ current untuk 3,3 Volt sebesar 50 $\mathrm{mA}$.

8) Flash memory $32 \mathrm{~KB}$.

9) SRAM $2 \mathrm{~KB}$.

10) EEPROM $1 \mathrm{~KB}$.

11) Clock Speed $16 \mathrm{MHz}$

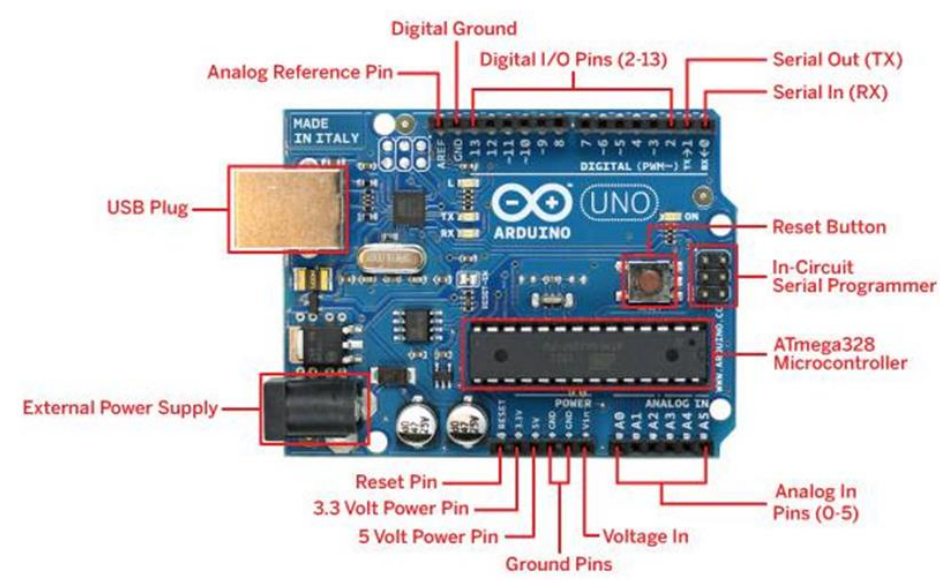

Gambar 4. Aduino Uno

(Sumber : $\underline{\text { http://www.arduino.cc) }}$

Sensor kelembaban tanah memiliki tiga pin yaitu bare, red, dan black yang memiliki 
fungsi masing-masing. Pin bare sebagai ground, pin red sebagai Vin (3,3 V-5 VDC) dan pin black sebagai output sensor (0-3 Volt). Setiap pin pada sensor YL-69 dihubungkan dengan mikrokontroler Arduino Uno ATMega328P, dimana pin Vin dihubungkan ke port 5 Volt, pin ground dihubungkan ke port ground dan pin Vout dihubungkan ke port analog serial A1 dan A2 pada mikrokontroler Arduino Uno ATMega328P. Sensor kelembaban tanah YL-69 ditanam pada lahan usahatani dengan kedalaman 5-10 cm (Cardenas-Lailhacar dan Dukes, 2010). Tabel 1 menunjukkan spesifikasi sensor kelembaban tanah YL-69 yang digunakan pada penelitian ini.

Tabel 1. Spesifikasi Sensor Kelembaban Tanah YL-6

\begin{tabular}{lc}
\hline \multicolumn{1}{c}{ Uraian } & Spesifikasi \\
\hline Tegangan suplai & 3,3 Volt atau 5 Volt \\
Current & $35 \mathrm{~mA}$ \\
Signal tegangan output & $0-4,2$ Volt \\
Digital output & 0 atau 1 \\
Analog & Resistance $(\Omega)$ \\
Dimensi panel & $1,6-3,0 \mathrm{~cm}$ \\
Dimensi probe & $3,0-6,0 \mathrm{~cm}$ \\
\hline
\end{tabular}

Pada blok mikrokontroler juga dipasang modul RTC dan micro SD sehingga dapat merekam data hasil pembacaaan sensor yang disertai dengan waktu pengukuran. Modul RTC dan micro $S D$ dipasang pada port 3 volt, port ground, port digital 10, port digital 11, port digital 12, dan port digital 13 yang terdapat pada mikrokontroler. Pada blok mikrokontroler terdapat beberapa rangkaian, antara lain inverter sebagai pengubah arus DC menjadi AC untuk mengoperasikan pompa elektris, relay sebagai saklar otomatis untuk menghidupkan atau mematikan sistem, terminal barrier, panel surya dan solar charge controller sebagai pendukung sistem dengan pemanfaatan tenaga surya, baterai 12 Volt sebagai sumber tegangan listrik yang akan dialirkan melalui relay untuk menggerakkan motor pompa elektris yang berfungsi sebagai buka-tutup aliran air yang akan mengalir ke jaringan irigasi (outlet irigasi) berupa sprinkler. Gambar 5 menunjukkan perangkat sistem kendali irigasi sprinkler otomatis bertenaga surya.

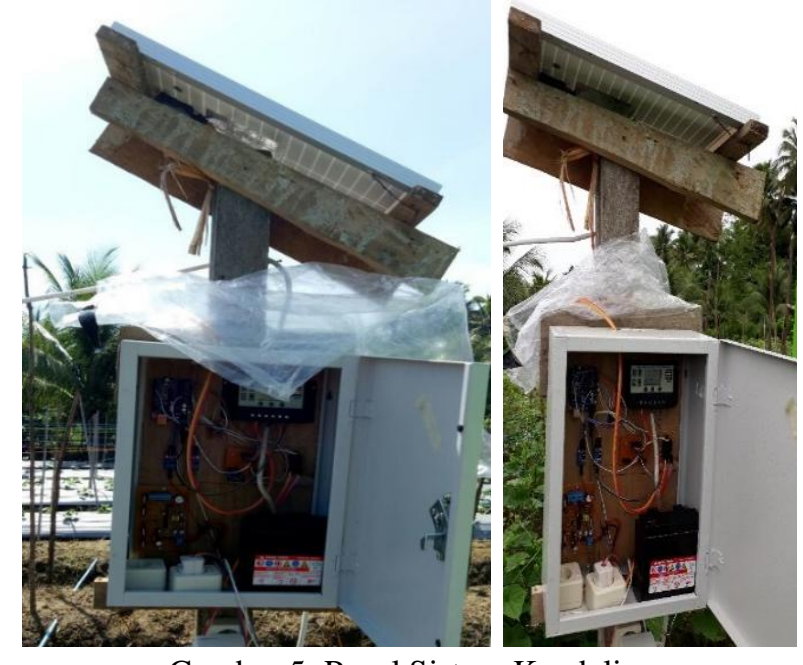

Gambar 5. Panel Sistem Kendali

Panel surya bekerja dengan cara mengubah energi panas dari sinar matahari ke energi listrik yang kemudian disimpan dalam sebuah baterai. Sel surya pada dasarnya adalah suatu elemen aktif yang mengubah cahaya matahari menjadi energi listrik. Konversi ini didasarkan pada fenomena efek Photovoltaic. Sinar matahari terdiri dari foton dengan tingkat energi yang berbeda tergantung spektrum dari mana sinar berasal. Ketika sinar matahari menerangi permukaannya, bahan Photovoltaic menyemburkan elektron yang menghasilkan tegangan listrik. Tabel 2 menunjukkan spesifikasi panel surya yang digunakan pada penelitian.

Tabel 2. Spesifikasi Panel Surya

\begin{tabular}{lc}
\hline \multicolumn{1}{c}{ Uraian } & Spesifikasi \\
\hline Daya Max (Pmax) & 30 Watt \\
Power Tolerance (\%) & $+/-3 \%$ \\
Max. Power Voltage (Vmp) & $17,60 \mathrm{~V}$ \\
Max. Power Current (Imp) & $1,70 \mathrm{~A}$ \\
Open Circuit Voltage (Voc) & $22,50 \mathrm{~V}$ \\
Short Circuit Current (Isc) & $1,82 \mathrm{~A}$ \\
Max. System Voltage & $700 \mathrm{~V}$ \\
Ketahanan suhu (C) & $-40 \mathrm{C} \sim+85 \mathrm{C}$ \\
Ukuran (mm) & $540 \times 350 \times 20$ \\
\hline
\end{tabular}

\section{Instalasi jaringan irigasi sprinkler}

Komponen utama pada sistem irigasi sprinkler meliputi sumber air, pompa dan tenaga penggerak sebagai sumber tekanan, pipa utama dan pipa lateral, dan sprinkler (Keller dan Bliesner, 1990). Irigasi sprinkler adalah suatu metode pemberian air pada lahan yang akan diirigasi dengan menggunakan pipa yang bertekanan melalui nozzle. Sistem sprinkler dapat diklasifikasikan menjadi sistem permanen (fixed/solid set), portable dan semi portable 
(hand move atau mechanical move), traveling irrigator (gun atau boom), center pivot atau linear move (Merkley dan Allen, 2004). Rancangan jaringan irigasi. sprinkler dipasang menggunakan sistem perpipaan pada lahan usaha berukuran $100 \times 100 \mathrm{~m}$ dan sistem pengaliran menggunakan pompa. Pipa utama yang berdiameter 1 inchi mengalirkan air ke pipa lateral yang berdiameter $1 / 2$ inchi dan merupakan outlet irigasi. Percobaan lapang dilakukan selama 7 hari secara kontinu dan pemberian air untuk tanaman dilakukan dengan menggunakan sprinkler yang bertekanan dari pom PS-130bit dengan spesifikasi pompa ditunjukan pada Tabel 3 berikut.

Tabel 3. Spesifikasi Pompa Irigasi

\begin{tabular}{lc}
\hline \multicolumn{1}{c}{ Uraian } & Spesifikasi \\
\hline Seri produk & PS-130 Bit \\
Voltage/Hz & $220 / 50$ \\
Daya Output Motor & $125 \mathrm{Watt}$ \\
Daya Input Motor & $0,3 \mathrm{~kW}$ \\
Panjang pipa hisap & $9 \mathrm{~m}$ \\
Daya dorong max & $40 \mathrm{~m}$ \\
Head / Kapasitas & $10 / 18 \mathrm{l} / \mathrm{min}$ \\
Head / Kapasitas & $22 / 101 / \mathrm{min}$ \\
Pipa hisap & $1 \mathrm{inch}$ \\
Pipa dorong & $1 \mathrm{inch}$ \\
\hline
\end{tabular}

Pemanfaatan teknologi irigasi sprinkler otomatis berbasis tenaga surya dapat meningkatkan efisiensi penggunaan energi dan dapat meminimalkan dampak terhadap lingkungan hidup jika dibandingkan dengan operasi pompa berbahan bakar minyak serta dapat mengatasi masalah kebutuhan listrik. Produk teknologi ini merupakan inovasi dalam upaya peningkatan efisiensi irigasi sekaligus merupakan teknologi otomatisasi yang lebih aplikatif serta memudahkan dalam pengaturan irigasi agar dapat mencapai peningkatan produktivitas air, tenaga kerja dan lahan pertanian.

Inovasi teknologi ini memperkenalkan sistem otomatis yang akan menjadi daya tarik untuk pengembangan pertanian modern, yang dapat mengatasi keterbatasan sumberdaya manusia di bidang pertanian serta tuntutan efisiensi penggunaan air dengan pengaturan otomatis sesuai pengaturan yang diinginkan. Penerapan teknologi irigasi sprinkler otomatis di lahan usaha tani dapat dilihat pada Gambar 6.

\section{Analisis Konsumsi Daya Untuk Pengoperasian Sistem}

Tenaga surya memberikan daya yang cukup untuk menggerakkan sistem dan dapat mengatasi masalah kebutuhan listrik selama percobaan lapang. Hidayah dan Prihantoko (2017) menyatakan bahwa penggunaan tenaga surya dengan daya $150 \mathrm{Wp}$ per satu sistem dan baterai $152 \mathrm{Ah}$, dapat mengoperasikan pintu air elektromekanis secara otomatis dengan acuan kendali data debit pada saluran dengan ketinggian maksimal satu meter. Penggunaan solar charge controller tipe LCD 12 Volt juga dapat menjaga agar baterai tidak kelebihan (over charge) dan kehabisan tegangan dengan begitu maka umur dari baterai bertambah lama. Tegangan charger yang dibutuhkan untuk pengisian baterai adalah 13,2-13,4 Volt dan jika sudah mencapai tegangan tersebut, maka rangkaian ini otomatis akan menghentikan proses pengisian tegangan baterai. Apabila tegangan baterai turun/drop hingga 11 Volt, maka controller akan memutus tegangan sehingga baterai tidak sampai kosong/habis. Hasil analisis konsumsi daya untuk pengoperasian sistem di lahan usahatani dapat dilihat pada Tabel 4.

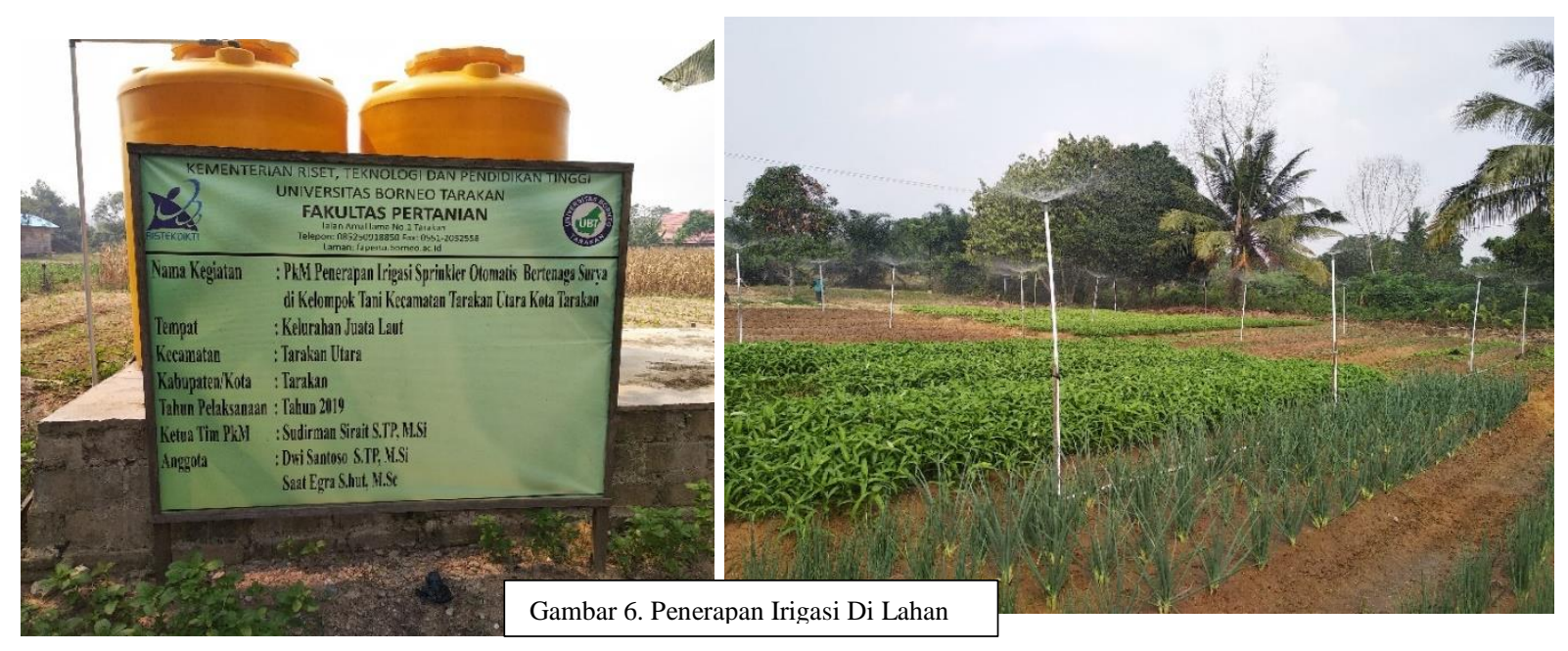


Tabel 4. Analisis konsumsi daya pada sistem kotrol irigasi sprinkler otomatis

\begin{tabular}{lc}
\hline \multicolumn{1}{c}{ Uraian } & $\begin{array}{c}\text { Konsumsi daya } \\
\text { selama percobaan }\end{array}$ \\
\hline $\begin{array}{l}\text { Pompa irigasi } \\
\text { Mikrokotroller Arduino Uno }\end{array}$ & 65,4 Watt \\
ATMega 328P & 1,08 Watt \\
RTC dan Micro SD & 0,008 Watt \\
Relay 12 V & 0,20 Watt \\
Relay 5 V & 0,12 Watt \\
Sensor kelembaban tanah & 0,24 Watt \\
Kapasitas max. solar cell 1 & 135 Watt \\
hari & 540 Watt \\
$\begin{array}{l}\text { Baterai 12V 45Ah } \\
\text { Lama daya tahan baterai } \\
\text { tanpa suplai dari solar cell }\end{array}$ & 8 Jam \\
$\begin{array}{l}\text { Kebutuhan baterai 7 hari } \\
\text { tanpa sinar matahari }\end{array}$ & 1,74 buah \\
Kebutuhan solar cell selama \\
percobaan
\end{tabular}

Konsumsi daya yang dibutuhkan untuk board Mikrokontroller adalah 7-12 Volt, jika diberi daya kurang dari 7 Volt kemungkinan Mikrokontroller dapat beroperasi tetapi tidak stabil. Jika diberi daya lebih dari 12 Volt, maka regulator tegangan akan panas dan dapat merusak board Mikrokontroller. Mikrokontroler dapat diaktifkan melalui catu daya eksternal yang berasal dari baterai dengan konektor power. Panel surya mampu menghasilkan tegangan hingga 0,5 Volt, jadi sebuah panel surya 12 Volt terdiri dari \pm 36 sel. Panel surya yang digunakan pada penelitian ini adalah panel surya $30 \mathrm{Wp}$ artinya panel surya tersebut mempunyai daya sebesar 30 Watt peak (saat matahari terik) dimana 1 peak diasumsikan selama 4,5 jam sehingga kapasitas maksimal untuk pemakaian 1 hari adalah 135 Watt.hourhari.

Total daya untuk mengoperasikan sistem irigasi sprinkler otomatis selama percobaan 7 hari secara kontinu adalah 67,0 Watt.hour, sehingga penggunaan 1 unit panel surya $30 \mathrm{Wp}$ mampu mencukupi daya yang dibutuhkan untuk mengoperasikan sistem irigasi sprinkler otomatis. Jika jaringan irigasi tidak dilengkapi dengan sistem kontrol otomatis, maka konsumsi daya pengoperasian pompa selama percobaan 7 hari sebesar 300 Watt, sehingga total daya untuk mengoperasikan irigasi sprinkler tanpa dilengkapi sistem kontrol otomatis adalah 301,7 Watt.hour. Maka penggunaan sistem kontrol otomatis pada jaringan irigasi sprinkler dapat menghemat penggunaan daya baterai sebesar 234,7 Watt. Penggunaan panel surya mampu mengurangi konsumsi energi lebih dari $35 \%$ sehingga dapat membantu meningkatkan pendapatan petani (Alam dan Naseem 2014).

\section{KESIMPULAN}

Kesimpulan dari penelitian ini adalah sebagai berikut :

1. Mikrokontroler Arduino Uno ATMega328P dapat digunakan sebagai sistem kendali otomatis untuk pengaturan on-off pompa irigasi berdasarkan kelembaban tanah yang dideteksi oleh YL-69 sensor kelembaban tanah.

2. Total daya yang dibutuhkan untuk mengoperasikan irigasi sprinkler otomatis adalah 67,0 Watt dan tanpa dilengkapi sistem kontrol otomatis adalah 301,7 Watt.hour.

3. Penggunaan sistem kontrol otomatis bertenaga surya pada jaringan irigasi sprinkler dapat menghemat penggunaan daya baterai sebesar 234,7 Watt.

\section{UCAPAN TERIMA KASIH}

Ucapan terima kasih disampaikan kepada Lembaga Penelitian dan Pengabdian Kepada Masyarakat (LP2M) Universitas Borneo Tarakan melalui Hibah DIPA Universitas Borneo Tarakan Skema Program Pengabdian Kepada Masyarakat Tahun 2019. Selain itu, ucapan terima kasih juga disampaikan kepada Kelompok Tani Cahaya Tani Kecamatan Tarakan Utara, Kota Tarakan, Kalimantan Utara sebagai mitra kegiatan Pengabdian kepada Masyarakat (PkM).

\section{DAFTAR PUSTAKA}

Balaji, V. R., Sudha, M. 2016. Solar powered auto irrigation system. International Journal of Emerging Technology in Computer Science \& Electronics (IJETCSE), 20(2).

Diperoleh dari http://www.ijetcse.com/wpcontent/plugins/ijetcse/file/upload/docx/379 ICAEECI-171-pdf.pdf.

Chavan, M. S., Pawar, P., Bhaga, R., Somanwad, N. 2017. Solar powered auto irrigation system. International Journal of Recent Innovation in Engineering and Research, 02, 19-24.

Dursun, M., Ozden, S. 2012. Application of solar powered automatic water pumping in Turkey. International Journal of Computer and Electrical Engineering, 4(2), 161-164. https://doi.org/DOI:10.7763/IJCEE.2012.V4 .471.

Hidayah, S., Prihantoko, A. 2017. Pintu Air Irigasi Elektromekanis Kombinasi Aliran Atas dan Bawah. Jurnal Irigasi, 11(2), 113-124. http://dx.doi.org/10.31028/ji.v11.i2.113124. 
Ingale, H., Kasat, N. N. 2012. Automated solar based agriculture pumping. International Journal of Advanced Research in Computer Science and Software Engineering, 2(11), 407-410.

Keller, J., Bliesner, R. D. 1990. Sprinkle and trickle irrigation. The Blackburn Press.

Merkley, G. P., Allen, R. G. 2004. Sprinkle \& Trickle Irrigation: Lecture Notes. Logan, Utah: Biological and Irrigation Engineering Department, Utah State Unive.

Nagahage, I. S. P., Dilrukshi, E. A. A. 2013. Solar powered automated irrigation system. Dipresentasikan pada ACEPS. Diperoleh dari http://dl.lib.mrt.ac.lk/handle/123/9076.

Nurfaijah, Setiawan, B. I., Arif, C., Widodo, S. 2015. Sistem Kontrol Tinggi Muka Air Untuk Budidaya Padi. Jurnal Irigasi, 10(2), 97-110. http://dx.doi.org/10.31028/ji.v10.i2.97-110.

Saptomo, S. K., Isnain, R., Setiawan, B. I. 2016. Irigasi curah otomatis berbasis sistem pengendali mikro. Jurnal Irigasi, 8(2), 115125. http://dx.doi.org/10.31028/ji.v8.i2.115$\underline{125}$.

Siebert, S., Döll, P. 2010. Quantifying blue and green virtual water contents in global crop production as well as potential production losses without irrigation. Journal of Hydrology, 384(3), 198-217. https://doi.org/10.1016/j.jhydrol.2009.07.03 $\underline{1}$.

Sirait S., Sri Maryati. 2018. Sistem kontrol irigasi sprinkler otomatis bertenaga surya di Kelompok Tani Kecamatan Meureubo Kabupaten Aceh Barat. Jurnal Irigasi, 13(1), 55-66.

http://dx.doi.org/10.31028/ji.v13.i1.55-66.

Tusi, A., Lanya, B. 2016. Rancangan Irigasi Sprinkler Portable Tanaman Pakchoy. Jurnal Irigasi, 11(1),

43-54. http://dx.doi.org/10.31028/ji.v11.i1.43-54.

Uddin, J., Reza, S. T., Newaz, Q., Uddin, J., Islam, T., Kim, J.-M. 2012. Automated irrigation system using solar power (hlm. 228-231). Dipresentasikan pada 7th International Conference on Electrical and Computer Engineering, Dhaka, Bangladesh: IEEE. https://doi.org/10.1109/ICECE.2012.647152 $\underline{7}$. 